Kumawula, Vol. 3, No.3, Desember 2020, Hal 405 - 415 DOI: https://doi.org/10.24198/kumawula.v3i3.27286

ISSN 2620-844X (online)

Tersedia online di http://jurnal.unpad.ac.id/kumawula/index

\title{
PENINGKATAN KAPASITAS EKONOMI MASYARAKAT MELALUI PEMBERDAYAAN KELOMPOK USAHA MIKRO KECIL DAN MENENGAH DI KAWASAN PANTAI UTARA DESA DOMAS KABUPATEN SERANG
}

\author{
Ahmad Sururi $^{1^{*}}$, Rahmi Mulyasih ${ }^{2}$, Budi Hasanah ${ }^{1}$, \\ Indrianti Azhar Firdausi ${ }^{2}$, Hasuri ${ }^{3}$, Hera Yuliani ${ }^{1}$ \\ ${ }^{1}$ Program Studi Administrasi Publik, Universitas Serang Raya \\ ${ }^{2}$ Program Ilmu Komunikasi, Universitas Serang Raya \\ ${ }^{3}$ Program Ilmu Hukum, Universitas Serang Raya \\ Korespondensi: ahmadbroer@gmail.com
}

\begin{abstract}
ABSTRAK
Tujuan dari kegiatan pengabdian masyarakat ini adalah memberdayakan dan meningkatkan kapasitas masyarakat desa tentang administrasi pengelolaan program, meningkatkan pengetahuan masyarakat desa tentang sistem pemasaran terpadu dan Mendorong peningkatan pemahaman kesadaran masyarakat terhadap KUKM. Output yang ingin dicapai dari kegiatan ini adalah meningkatnya kapasitas ekonomi masyarakat melalui pemberdayaan kelembagaan Kelompok Usaha Mikro Kecil dan Menengah (KUMKM) sebagai instrumen ekonomi masyarakat yang dibentuk secara swadaya. Metode kegiatan pengabdian masyarakat yang digunakan adalah gabungan dari dua metode pemberdayaan masyarakat yaitu Participatory Rapid Appraisal (PRA) atau penilaian desa secara partisipatif dan Participatory Learning and Action (PLA) atau proses belajar/praktik secara partisipatif. Hasil kegiatan pengabdian masyarakat berjalan sesuai dengan rencana yang telah ditetapkan, masyarakat memilki respon dan antusias terhadap pelatihan dan terciptanya derajat perubahan pengetahuan, sikap dan keterampilan dengan besaran nilai 67,14 dan 62,50 atau berada pada kategori cukup.
\end{abstract}

Kata kunci : Pemberdayaan, Kapasitas Ekonomi, Kelompok Usaha Kecil dan Menengah

\begin{abstract}
The purpose of this community service activity includes to empower and enhance the capacity of village communities in program management administration, increasing the knowledge of rural communities about integrated marketing systems and to encourage increased understanding of public awareness of SMEs. The output to be achieved from this activity is to increase the economic capacity of the community through the empowerment of the KUKM institution as a community economic instrument formed independently. The method used is a combination of two methods of community empowerment, namely Participatory Rapid Appraisal (PRA) or participatory village assessments and Participatory Learning and Action (PLA) or participatory learning/practice processes. The results of community service activities went according to a predetermined plan, the community has shown a positive response and enthusiasm for training and the creation of degrees of change in knowledge, attitudes and skills with a magnitude of 67.14 and 62.50 or are in the sufficient category.
\end{abstract}

Keywords: Empowerment, Economic Capacity, Small and Middle Business Group

\section{PENDAHULUAN}

Salah satu faktor yang memengaruhi perkembangan suatu desa adalah peran dan komitmen dari aparat pemerintahan desa untuk melaksanakan program-program desa yang dapat memberikan dampak positif kepada masyarakat. Selain itu, kemampuan masyarakat untuk mengembangkan dan memanfaatkan potensi sumber daya lokal yang tersedia menjadi faktor penting sebagai bentuk 
dukungan terhadap implementasi programprogram desa tersebut. Hal ini sejalan dengan paradigma pembangunan perdesaan yang fokus terhadap kemampuan masyarakat untuk mengembangkan dan memanfaatkan potensi sumber daya lokal dan tata kelola pembangunan antar sektor yang terintegrasi di berbagai wilayah di perdesaan secara mandiri termasuk dalam hal pengembangan usaha kecil formal dan non formal. Bahwa pengembangan usaha kecil secara formal dan non formal diharapkan dapat memberikan dampak terhadap keterkaitan berbagai sektor dengan sektor lokal atau tradisional di pedesaan (Widodo, 2007). Dalam hal ini berbagai upaya untuk mendorong berkembangnya potensi masyarakat lokal yang sesuai dengan kebutuhan harus terus dilakukan agar dapat memberikan dampak kemandirian ekonomi masyarakat.

Potensi dan peluang ekonomi yang secara mandiri harus mendapatkan perhatian dan dapat meningkatkan kesejahteraan ekonomi masyarakat secara berkelanjutan adalah wilayah pesisir pantai yang sebagian besar dihuni oleh masyarakat nelayan yang terletak kawasan pantai utara pulau Jawa yaitu di Desa Domas Kecamatan Pontang Kabupaten Serang. Hal ini dikarenakan pembangunan wilayah pesisir perlu memperoleh perhatian yang cukup karena aset serta sumber daya pesisir dan lautan mempunyai potensi yang besar untuk mendukung pembangunan nasional (Ekosafitri et al., 2017). Selain itu terdapat dua alasan mengapa pembangunan wilayah pesisir harus maupun keuntungan lokasi (location advantage) seperti budi daya tambak, perikanan tangkap, industri pariwisata dan permukiman; 2)memperhatikan kaidah kelompok individu dan masyarakat yang mempunyai keterampilan dan keahlian bekerja sebagai nelayan, petani tambak, petani rumput laut, pendamping pariwisata dan industri kerajinan (Nugroho \& Dahuri, 2012).

Produksi tangkapan ikan di kawasan Pantai utara Desa Domas Kecamatan Pontang selama ini diolah oleh Kelompok Usaha Mikro Kecil dan Menengah (KUMKM) yang merupakan kelompok ekonomi dan dibentuk secara mandiri oleh masyarakat dengan tujuan untuk mendukung pertumbuhan ekonomi masyarakat. Aktivitas utama KUMKM tersebut adalah mengelola hasil tangkap ikan agar memiliki nilai tambah ekonomi dengan lebih maksimal melalui diversifikasi aneka ragam bahan makanan seperti kerupuk ikan, abon ikan, bontot, terasi, keropcok, dan ikan asin. Dalam hal ini masyarakat secara mandiri berupaya untuk meningkatkan pendapatan ekonomi melalui konsep pemberdayaan ekonomi sebagai suatu program pemberdayaan masyarakat yang dirancang untuk menanggulangi ketertinggalan merupakan bagian dari upaya untuk mempercepat proses perubahan kondisi sosiolekonomi masyarakal yang masih tertinggal (Sumodiningrat, 1999).

Berikut adalah jumlah, kondisi, program dan pemasaran KUMKM di Desa Domas yaitu sebagai berikut :

Tabel 1. Kelompok KUMKM, Program dan Pemasaran

\begin{tabular}{|c|c|c|c|c|}
\hline No & $\begin{array}{l}\text { Nama Kelompok } \\
\text { KUMKM/Industri }\end{array}$ & Kondisi & Program & Pemasaran \\
\hline 1 & Ikan Asin & Baik & $\begin{array}{l}\text { Pengelolaan hasil } \\
\text { tangkap ikan }\end{array}$ & $\begin{array}{l}\text { Masyarakat sekitar dan } \\
\text { luar desa }\end{array}$ \\
\hline 2 & Keropcok & Baik & $\begin{array}{l}\text { Pengelolaan hasil } \\
\text { tangkap ikan }\end{array}$ & $\begin{array}{l}\text { Masyarakat sekitar dan } \\
\text { luar desa }\end{array}$ \\
\hline 3 & Bontot dan Kerupuk & Baik & $\begin{array}{l}\text { Pengelolaan hasil } \\
\text { tangkap ikan }\end{array}$ & $\begin{array}{l}\text { Masyarakat sekitar dan } \\
\text { luar desa }\end{array}$ \\
\hline 4 & Abon Ikan & Baik & $\begin{array}{l}\text { Pengelolaan hasil } \\
\text { tangkap ikan }\end{array}$ & $\begin{array}{l}\text { Masyarakat sekitar dan } \\
\text { luar desa }\end{array}$ \\
\hline 5 & Dendeng Ikan & Baik & $\begin{array}{l}\text { Pengelolaan hasil } \\
\text { tangkap ikan }\end{array}$ & Masyarakat sekitar \\
\hline
\end{tabular}

Sumber : Tim PKM, 2019

memenuhi kaidah keberlanjutan (sustainability)

diantaranya adalah sebagai berikut:

1)memperhatikan kaidah adanya ragam ekologi
Program pengabdian kepada masyarakat merupakan suatu upaya peningkatan dan pengembangan bersama antara 
peneliti, masyarakat lokal dan pemerintah daerah serta pemangku kepentingan lainnya, bahwa masyarakat telah memiliki pengetahuan lokal (indigenous knowledge) dalam mengelola lingkungannya, pemerintah daerah memiliki program pengembangan wilayah melalui berbagai program pembangunan dan peneliti memiliki konsep-konsep dan prinsip-prinsip dalam pengelolaan lingkungan (Abdoellah et al., 2019). Hal tersebut sejalan dengan konsep dan perubahan paradigma pembangunan desa yang selama ini terpusat atau menempatkan desa sebagai objek menjadi desentralisasi atau menempatkan desa sebagai subjek sekaligus melakukan pemberdayaan masyarakat yang inovatif dam partisipatif yang memberikan prioritas dan ruang bagi masyarakat untuk berpartisipasi dan berkembang sesuai dengan karakteritsik dan potensi lokal yang dimiliki (Sururi \& Mulyasih, 2017).

Berdasarkan hasil observasi dan wawancara awal tim Pengabdian Kepada Masyarakat (PKM) ditemukan permasalahan bahwa keberadaan KUMKM masih belum optimal dalam meningkatkan pendapatan ekonomi masyarakat pesisir, hal ini disebabkan karena masih minimnya pengetahuan masyarakat dalam pengelolaan program dan kelembagaan KUMKM, minimnya akses pemasasaran, keterbatasan modal serta masih rendahnya tingkat kesaadaran warga desa untuk bekerjasama memajukan KUMKM. Berdasarkan informasi yang didapatkan, bahwa pada tahun 2015 dan 2016 KUMKM pernah mendapatkan bantuan dari Dinas Perindustrian Perdagangan dan Koperasi berupa modal dan sarana prasarana pembuatan makanan. Selain itu informasi yang didapatkan oleh tim PKM adalah bantuan yang pernah diterima dari Dinas Perdagangan, Perindustrian dan Koperasi Kabupaten Serang seperti bantuan pembelian bahan baku seperti tepung, bawang putih dan minyak goreng dengan harga murah dan bantuan modal pernah diberikan pada tahun 2017 sedangkan fasilitasi kegiatan berupa peningkatan kapasitas masyarakat belum dilakukan.

Dengan demikian, melihat berbagai permasalahan terutama dalam meningkatkan kapasitas sumber daya masyarakat wilayah pesisir dalam pengelolaan program dan kelembagaan KUMKM, maka solusi yang ditawarkan tim PKM adalah mengadakan kegiatan pengabdian masyarakat melalui peningkatan kapasitas ekonomi masyarakat melalui pemberdayaan kelembagaan KUMKM dengan fokus terhadap tiga hal yaitu pelatihan administrasi pengelolaan program KUKUM, bimbingan komunikasi pemasaran dan pemahaman peningkatan kesadaran masyarakat.

Mitra pengabdian tim PKM adalah masyarakat Desa Domas yang terletak disebelah Utara Kecamatan Pontang dengan luas wilayah 796 Ha. Letak Ketinggian dari permukaan laut sekitar +1.5Meter. Desa Domas terdiri dari lima Kampung yaitu Kampung Domas, Kampung Wanayasa, Kampung Sampang Kulon, Kampung Pepetan dan Kampung Baru Cerocoh, dengan luas keseluruhan wilayah $1.752 \mathrm{Ha}$ dan dihuni dengan jumlah penduduk sebanyak 2.393 Jiwa dan 333 Kepala Keluarga (KK).

Rumusan masalah yang menjadi fokus kegiatan pengabdian masyarakat ini adalah bagaimana sosialisasi dan pelatihan pengelolaan program, bimbingan pemasaran dan pemahaman peningkatan kesadaran masyarakat dalam mewujudkan tujuan KUMKM. Adapun tujuan dari kegiatan pengabdian masyarakat ini adalah: memberdayakan dan meningkatkan kapasitas masyarakat desa tentang administrasi pengelolaan program, meningkatkan pengetahuan masyarakat desa tentang sistem pemasaran terpadu dan mendorong peningkatan pemahaman kesadaran masyarakat terhadap KUMKM.

\section{METODE}

Metode kegiatan pengabdian masyarakat yang digunakan adalah gabungan dari dua metode pemberdayaan masyarakat yaitu Participatory Rapid Appraisal (PRA) atau penilaian desa secara partisipatif dan Participatory Learning and Action (PLA) atau proses belajar/praktik secara partisipatif. 
Metode pemberdayaan masyarakat PRA diartikan sebagai sekumpulan pendekatan dan metode yang mendorong masyarakat pedesaan untuk ikut serta meningkatkan dan menganalisis pengetahuan mengenai hidup dalam konteks kondisi masyarakat agar dapat membuat rencana dan tindakan (Chambers, 1994). Metode PRA atau penilaian desa secara partisipatif dalam pengabdian masyarakat ini dilakukan melalui berbagai kegiatan sebagai berikut:

1) Analisis Situasi Sosial yaitu melakukan analisis sosial ekonomi masyarakat secara partisipatif melalui survei kampung bersama (SKB), observasi dan wawancara. Pada tahap ini, tim PKM melakukan identifikasi tentang kondisi sosial dan ekonomi masyarakat sekarang dan perubahan-perubahan yang terjadi, alasanalasan atau penyebabnya, identifikasi permasalahan dan alternatif-alternatif pemecahan masalah.

2) Pemilihan alternatif atau solusi pemecahan masalah yang paling dapat dilaksanakan, efisien dan diterima masyarakat.

3) Pelibatan dan peran stakeholders, jumlah dan sumber-sumber pembiayaan untuk melaksanakan program kegiatan yang akan direkomendasikan.

PRA memungkinkan masyarakat desa mampu mengungkapkan dan menganalisis situasi mereka sendiri secara optimal merencanakan dan melaksanakan tekad di desanya sendiri (Chambers, 1994). Metode pemberdayaan masyarakat PLA dilakukan dengan fokus pada kegiatan

Tahap Perencanaan yaitu dengan melakukan analisis situasi sosial
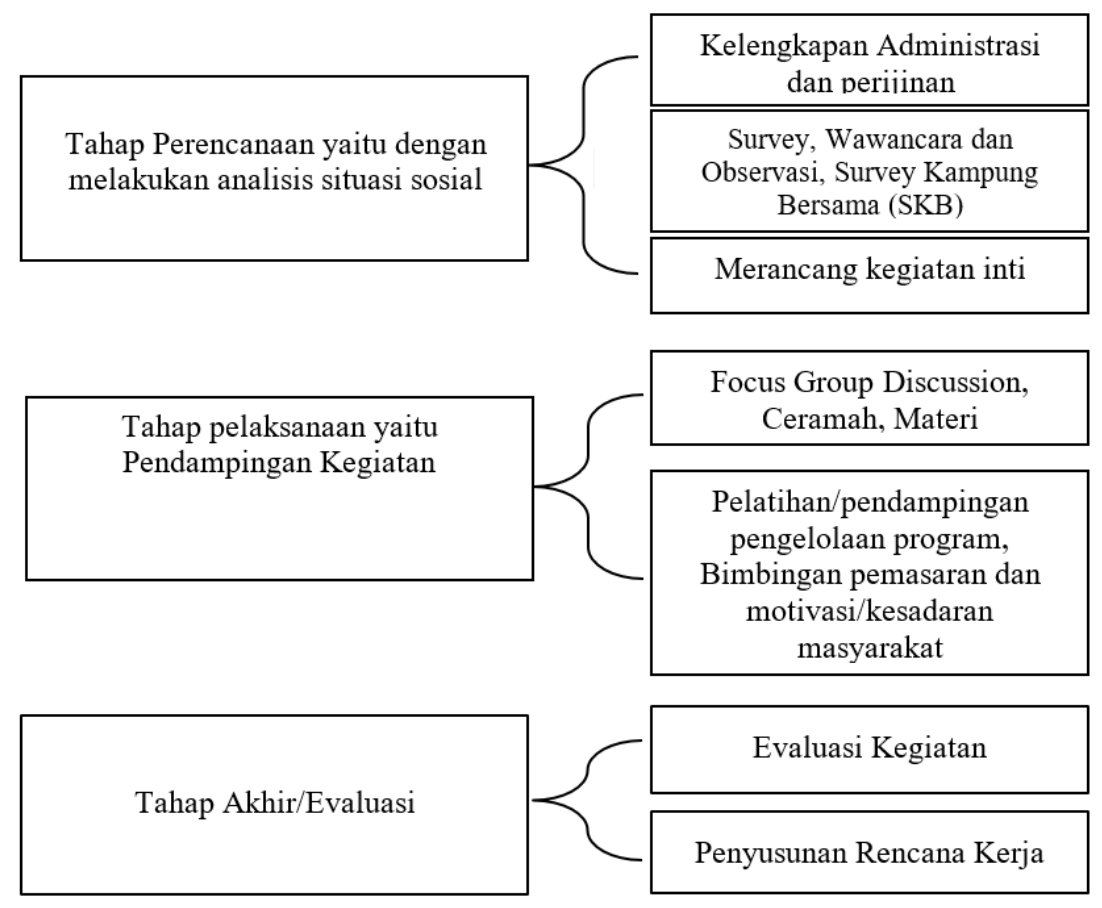

Gambar 1

Tahapan Kegiatan Pengabdian Masayarakat Sumber: Tim PKM Desa Domas Pontang, 2020

sosialisasi, Focus Group Discussion, ceramah, diskusi tanya jawab dan bimbingan yang dilakukan secara interaktif dengan masyarakat dan dilanjutkan dengan aksi atau kegiatan riil 
Berikut ini penjelasan pada masing-masing tahap kegiatan.

1. Tahap perencanaan yaitu dengan melakukan analisis situasi sosial. a)mengurus perijinan dan kelengkapan perijinan dengan melakukan kunjungan ke Kantor Desa untuk menemui Kepala Desa, Aparat Pemerintah Desa, Ketua Badan Permusyawaratan Desa, tokoh masyarakat, tokoh agama dan tokoh pemuda untuk memberikan sosialisasi berupa informasi dan menjelaskan maksud dan tujuan Tim PKM; b)melakukan kunjungan dan Survei Kampung Bersama (SKB) dengan beberapa warga desa untuk melakukan wawancara kepada beberapa kepala keluarga dan melakukan pengamatan di beberapa lokasi seperti bangunan KUMKM, tempat pengolahan ikan dan rumah warga (c)menyusun rancangan kegiatan pelatihan sesuai dengan kebutuhan mitra.

2. Tahap pelaksanaan/pendampingan kegiatan. Pada tahap ini dilakukan kegiatan pelatihan administrasi pengelolaan program, bimbingan pemasaran dan pemahaman peningkatan kesadaran masyarakat bekerjasama dengan aparatur Desa dan masyarakat Desa Domas Kecamatan Pontang Kabupaten Serang.

3. Tahap akhir atau evaluasi yang bertujuan untuk menilai dan mengukur kapasitas masyarakat setelah menerima kegiatan pendampingan dan pelatihan. Kegiatan evaluasi dilakukan dengan melihat indikator tahapan kemampuan masyarakat dalam menerima pengelolaan program, bimbingan pemasaran dan perubahan pemamahan dan kesadaran masyarakat dengan berdasarkan skala interval sebagai berikut :
Tahap selanjutnya adalah penyusunan rencana kerja Program Unggulan Desa (PUD) berbasis pendekatan partisipatif masyarakat dan kerjasama antara aparat Pemerintahan Desa dan Tim PKM sebagai fasilitator.

\section{HASIL DAN PEMBAHASAN}

Kegiatan pendampingan ini dilakukan selama 2 (dua) minggu yaitu minggu pertama s/d minggu kedua bulan Januari 2020.

\section{Tahap Perencanaan/Analisis Situasi Sosial}

Hasil kegiatan perencanaan berupa analisis situasi sosial diawali dengan melakukan kunjungan sosialisasi kepada apatur pemerintahan Desa Domas dan pendekatan kepada tokoh masyarakat, tokoh agama dan tokoh pemuda. Pada tahap ini, dilakukan wawancara dalam suasana kekeluargaan dan kesimpulan hasil wawancara, tim PKM mendapatkan respon positif dari kepala desa untuk menerima tim PKM dalam melakukan kegiatan pengabdian masyarakat di Desa Domas. Dengan modal sosial dan pendekatan kekeluargaan sebagai sesama masyarakat pribumi Banten, hasil kegiatan kunjungan berlangsung dalam suasana keakraban, harmonis dan saling memberikan pemahaman tentang pentingnya kegiatan pengabdian untuk masyarakat.

Selanjutnya kegiatan Tim PKM melakukan kunjungan dan Survei Kampung Bersama (SKB) dengan beberapa warga desa untuk melakukan wawancara kepada beberapa kepala keluarga dan melakukan pengamatan di beberapa lokasi seperti bangunan KUMKM, tempat pengolahan ikan dan rumah warga. Tujuan utama kegiatan ini adalah untuk melakukan pendataan dan identifikasi potensi sumber daya desa dan fokus permasalahan yang menjadi hambatan masyarakat dalam

Tabel 2

Skala Interval Evaluasi Pengukuran Kapasitas Masyarakat

\begin{tabular}{ccc}
\hline No & Skala Interval & Keterangan \\
\hline 1 & $0-25$ & Sangat Tidak Baik \\
\hline 2 & $26-50$ & Kurang Baik \\
\hline 3 & $51-75$ & Cukup Baik \\
\hline 4 & $76-100$ & Sangat Baik \\
\hline
\end{tabular}


mengembangkan KUMKM yang sudah berjalan.

Matrik hasil tahap perencaanaan/analisis sosial setting dari kegiatan tersebut digambarkan dalam tabel sebagai berikut :

\section{a) Hasil Sosialisasi pengabdian masyarakat dan Focus Group Discussion (FGD)}

Hasil kegiatan sosialisasi pengabdian masyarakat dan FGD yang dilaksanakan pada tanggal 04 Januari 2020 dan dihadiri oleh

Tabel 3

Matrik hasil Tahap Perencanaan/

Analisis Situasi Sosial, Kunjungan dan SKB

\begin{tabular}{|c|c|c|}
\hline No & $\begin{array}{c}\text { Aspek yang menjadi Fokus Pengabdian } \\
\text { Masyarakat }\end{array}$ & Temuan Potensi dan Permasalahan \\
\hline 1 & Kelembagaan Desa & $\begin{array}{l}\text { Desain perangkat kelembagaan menggunakan } \\
\text { pendekatan kombinasi antara pola modern dan } \\
\text { tradisional dengan dukungan sumber daya memadai } \\
\text { dan kantor desa representatif. }\end{array}$ \\
\hline 2 & Manajemen pelayanan aparatur desa & $\begin{array}{l}\text { Sudah dilakukan pelayanan secara optimal akan tetapi } \\
\text { belum memberikan kepuasan kepada masyarakat dari } \\
\text { sisi kecepatan pelayanan dikarenakan minimnaa } \\
\text { kompetensi sumber daya manusia dalam penguasaan } \\
\text { teknologi. }\end{array}$ \\
\hline 3 & Pengelolaan Program kelembagaan KUKM & $\begin{array}{l}\text { - Meskipun dalam beberapa aspek pengelolaan } \\
\text { program sudah dilaksanakan dengan baik akan } \\
\text { tetapi perkembangannya masih bersifat stagnan } \\
\text { Minimnya kapasitas pengurus dan anggota } \\
\text { KUKM dalam pengelolaan program }\end{array}$ \\
\hline 4 & Cakupan Pemasaran & $\begin{array}{l}\text { Pemasaran masih dilakukan secara terbatas dan belum } \\
\text { menjangkau wilayah di luar desa dan kecamatan } \\
\text { secara luas. }\end{array}$ \\
\hline 5 & $\begin{array}{l}\text { Tingkat } \quad \text { Pemahaman } \\
\text { Masyarakat terhadap KUKM }\end{array}$ & $\begin{array}{l}\text { Kemauan masyarakat untuk maju sangat tinggi } \\
\text { meskipun terdapat keterbatasan pemahaman dan } \\
\text { minimnya pengetahuan }\end{array}$ \\
\hline
\end{tabular}

Sumber : Tim PKM Desa Domas Pontang, 2020

\section{Tahap pelaksanaan/pendampingan kegiatan.}

Merupakan tahap inti kegiatan pengabdian kepada masyarakat, pada tahap ini fokus kegiatan meliputi pelatihan administrasi pengelolaan program KUMKM, bimbingan komunikasi pemasaran dan pemahaman peningkatan kesadaran masyarakat bekerjasama dengan aparatur dan masyarakat Desa Domas. Adapun jadwal kegiatan PKM dapat dilihat pada tabel berikut ini : aparatur pemerintahan Desa Domas seperti kepala desa, ketua BPD dan masyarakat serta bertempat di Kantor Kepala Desa berjalan dengan baik dan lancar. Seluruh pelaksanaan kegiatan sosialisasi dan FGD berjalan sesuai dengan rencana yang telah ditetapkan.

Respon masyarakat dan KUMKM dalam menerima sosialisasi yang diberikan oleh tim PKM sangat positif dan Antusias. Rangkaian kegiatan diawali dengan memberikan informasi kepada masyarakat terkait waktu kegiatan yang akan dilaksanakan selama dua minggu dan materi yang akan

Tabel 4

Jadwal Pelakasnaan/pendampingan kegiatan

\begin{tabular}{clcc}
\hline No & \multicolumn{1}{c}{ Kegiatan } & Waktu & Ket. \\
\hline 1 & Sosialisasi dan FGD & 04 Januari 2020 & $\begin{array}{c}\text { Ahmad Sururi, M.Si } \\
\text { (Koordinator) dan Tim PKM }\end{array}$ \\
\hline 2 & $\begin{array}{l}\text { Pelatihan administrasi pengelolaan } \\
\text { program, }\end{array}$ & 05 Januari 2020 & $\begin{array}{c}\text { Budi Hasanah, M.Si } \\
\text { (Koordinator) dan Tim PKM }\end{array}$ \\
\hline 3 & $\begin{array}{l}\text { Bimbingan Pemasaran dan } \\
\text { komunikasi Media }\end{array}$ & 11 Januari 2020 & $\begin{array}{c}\text { Rahmi Mulyasih, M.Si dan } \\
\text { Indrianti Azhar, M.Ikom } \\
\text { (Koordinator) dan Tim PKM }\end{array}$ \\
\hline 4 & $\begin{array}{l}\text { Pemahaman peningkatan } \\
\text { kesadaran masyarakat }\end{array}$ & 12 Januari 2020 & $\begin{array}{c}\text { Hasuri } \\
\text { (Koordinator) dan Tim PKM }\end{array}$ \\
\hline
\end{tabular}


diberikan. Selanjutnya kegiatan sosialisasi dan FGD dari Tim PKM membagi masyarakat menjadi beberapa kelompok untuk dilakukan diskusi berkelompok secara terfokus atau terarah berdasarkan permasalahanpermasalahan yang sudah ditemui, hal ini bertujuan agar Tim PKM dapat memetakan masalah dan mendapatkan masukan dari masyarakat.

Dalam kegiatan FGD yang sudah dilaksanakan, sebagian besar masyarakat mampu mengemukakan pendapat, masukan dan solusi dengan bimbingan dari tim PKM, dialog berlangsung antara sesama anggota masyarakat dalam suasana kekeluargaan meskipun ditemukan perbedaan pemahaman akan tetapi terdapat substansi dan tujuan yang sama yaitu menginginkan kemajuan KUKM bersamasama. Hasil dari sosialisasi dan FGD digambarkan dalam tabel berikut ini :

\section{b) Kegiatan Pelatihan/Pendampingan Pengelolaan program dan Kelembagaan KUMKM}

Kegiatan pelatihan/pendampingan diikuti oleh pengurus KUMKM/masyarakat Desa Domas berjumlah 15 (lima belas) orang sebagai perwakilan dari setiap Rukun Tetangga yang telah ditunjuk dan dihadiri oleh aparatur pemerintahan Desa Domas yang berjumlah lima orang sehingga total peserta kegiatan sebanyak 20 orang. Kegiatan yang dilaksanakan pada tanggal 05 Januari 2020 ini meliputi materi teori $25 \%$ dan praktek $75 \%$. Prosentase praktek diberikan lebih besar dikarenakan sesuai dengan kebutuhan masyarakat dan bertujuan agar pengurus/masyarakat mampu secara mandiri mempraktekkan penyusunan rencana kerja dan program, KUMKM, kegiatan monitoring dan evaluasi selama implementasi program KUMKM dan penyusunan laporan pertanggungjawaban Anggaran KUKMM.

Tabel 5

Hasil Sosialisasi dan FGD

\begin{tabular}{|c|c|c|}
\hline No & $\begin{array}{c}\text { Temuan Potensi dan } \\
\text { Permasalahan } \\
\end{array}$ & Masukan dan Solusi \\
\hline 1 & $\begin{array}{l}\text { Desain perangkat kelembagaan } \\
\text { menggunakan pendekatan kombinasi } \\
\text { antara pola modern dan tradisional, } \\
\text { sumber daya cukup dan kantor desa } \\
\text { representatif. }\end{array}$ & $\begin{array}{l}\text { Mempertahankan desain perangkat } \\
\text { kelembagaan yang sudah ada dengan } \\
\text { melakukan inovasi perangkat berdasarkan } \\
\text { kebutuhan masyarakat. }\end{array}$ \\
\hline 2 & $\begin{array}{l}\text { Sudah dilakukan pelayanan secara } \\
\text { optimal akan tetapi belum } \\
\text { memberikan kepuasan kepada } \\
\text { masyarakat dari sisi kecepatan } \\
\text { pelayanan dikarenakan minimnya } \\
\text { kompetensi sumber daya manusia } \\
\text { dalam penguasaan teknologi. }\end{array}$ & $\begin{array}{l}\text { Melakukan peningkatan kompetensi } \\
\text { sumber daya manusia dalam penguasaan } \\
\text { teknologi melalui pelatihan keterampilan } \\
\text { penggunaan komputer dan pemasangan } \\
\text { internet di Kantor desa untuk menunjang } \\
\text { kecepatan pelayanan }\end{array}$ \\
\hline 3 & 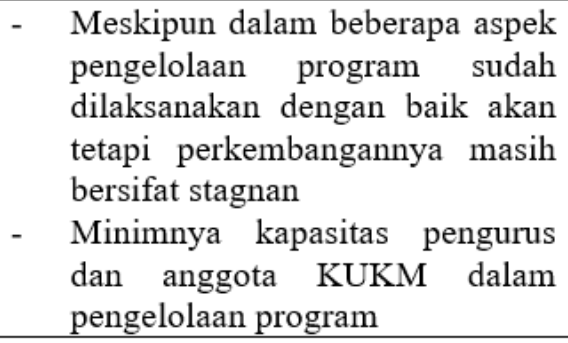 & $\begin{array}{l}\text { Mendukung dan melaksanakan kegiatan } \\
\text { pelatihan/pendampingan kepada pengurus } \\
\text { dan masyarakat desa melalui kegiatan } \\
\text { penguatan kapasitas eknoomi masyarakat } \\
\text { melaui pemberdayaan KUKM. }\end{array}$ \\
\hline 4 & $\begin{array}{l}\text { Pemasaran masih dilakukan secara } \\
\text { terbatas dan belum menjangkau } \\
\text { wilayah di luar desa dan kecamatan } \\
\text { secara luas. }\end{array}$ & $\begin{array}{l}\text { Mendukung pelaksanaan kegiatan } \\
\text { pelatihan komunikasi pemasaran }\end{array}$ \\
\hline 5 & $\begin{array}{l}\text { Kemauan masyarakat untuk maju } \\
\text { sangat tinggi meskipun terdapat } \\
\text { keterbatasan pemahaman }\end{array}$ & $\begin{array}{lll}\text { Mendukung pelaksanaan } & \text { kegiatan } \\
\text { pemberian pengetahuan dan motivasi } \\
\text { kepada masyarakat }\end{array}$ \\
\hline
\end{tabular}

Sumber: Tim PKM Desa Domas Pontang, 2020 
Hasil kegiatan Tim PKM menyimpulkan bahwa peserta kegiatan dari unsur masyarakat yang diwakili oleh beberapa lulusan SMK dan SMA secara sederhana sudah mampu mengoperasioan laptop dengan microsoft office

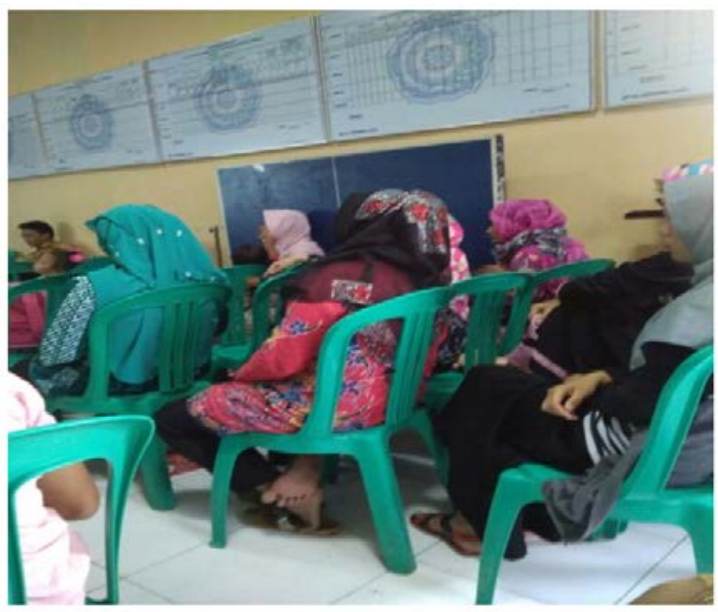

Gambar. 2

Kegiatan Pengabdian Masyarakat KUKM

Desa Domas Kecamatan Pontang

dan microsoft excel sehingga memberikan kemudahan bagi tim PKM dalam menyampaikan materi yang diberikan. Selain itu hasil kegiatan pelatihan/pendampingan menunjukkan bahwa peserta memiliki respon dan semangat yang cukup baik serta memperlihatkan animo keingintahuan yang besar.

Pada pelaksanaan kegiatan yang sudah dilakukan, tim PKM berperan sebagai fasilitator melalui metode PLA kepada masyarakat dengan membagi peserta menjadi menjadi lima kelompok dengan masing-masing jumlah anggota sebanyak empat orang dan diberikan beberapa contoh laporan untuk dipraktekkan menggunakan media alat tulis yang sudah disediakan. Hasil laporan dari masing-masing kelompok selanjutnya didiskusikan bersama tim PKM maupun dengan kelompok lain untuk saling memberikan pertanyaan, masukan dan jawaban.

Pada kegiatan ini, masyarakat mengajukan pertanyaan-pertanyaan mengenai materi yang masih belum jelas dan belum dipahami. Output yang ingin diharapkan dari kegiatan pelatihan/pendaampingan ini adalah menumbuhkan partisipasi masyarakat dan peningkatan kemampuan masyarakat secara mandiri dan bertahap dalam melakukan penyusunan laporan sederhana, menyusun laporan monitoring dan evaluasi program dan laporan pertanggungjawaban keuangan KUMKM.

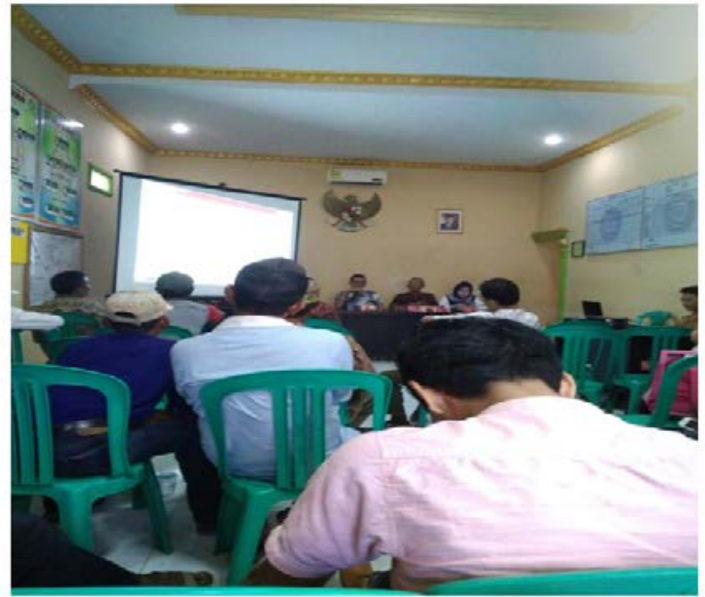

\section{c) Kegiatan}

Pelatihan/Pendampingan Bimbingan Komunikasi Pemasaran

Kegiatan yang dilaksanakan pada tanggal 11 Januari 2020 ini mencakup materi strategi pemasaran melalui pemanfaatan media komunikasi efektif. Penerapan metode PLA dalam kegiatan ini dilakukan dengan membagi total jumlah peserta menjadi beberapa berkelompok dan menggunakan contohcontoh komunikasi pemasaran seperti brosur, flyer dan promosi online yang diberikan kepada peserta. Implementasi promosi dan pemasaran produk-produk aneka ragam makanan ikan Desa Domas Kecamatan Pontang diberikan contoh dengan membuat konten di media sosial seperti blog, instagram, twitter dan facebook.

Meksipun dengan keterbatasan akan tetapi semangat dari peserta kegiatan cukup baik, dialog dan diskusi antar kelompok dan tim PKM berjalan kondusif dan memperlihatkan adanya keinginan masyarakat untuk kemajuan KUMKM. Pada tahap selanjutnya, bimbingan dari tim PKM pada aspek pemasaran di media sosial dan rencana mengoptimalkan BUMDesa dan sentra pemasaran akan ditindaklanjuti. 
d) Kegiatan Pendampingan Motivasi dan kesadaran masyarakat

Kegiatan ini mencakup bimbingan motivasi kepada masyarakat tentang pentingnya KUMKM. Tim PKM melakukan stressing atau penekanan bahwa KUMKM adalah milik masyarakat dan lahir dari masyarakat sehingga kemajuan dan kemunduran KUMKM adalah tanggung jawab bersama seluruh masyarakat. Selanjutnya dilakukan dialog yang membahas tentang apa permasalahan dan hambatan masyarakat yang masih belum termotivasi untuk bersama-sama memajukan KUMKM.

\section{Tahap Akhir/Evaluasi Pelatihan}

Dan untuk mengetahui bagaimana tingkat keberhasilan pencapaian kegiatan pelatihan pendampingan yang telah dilaksanakan, dilakukan evaluasi melalui indikator tahapan perubahan perilaku pengetahuan, sikap dan keterampilan yang dapat dilihat pada tabel 6 sebagai berikut: cukup baik, meskipun terdapat keterbatasan pendidikan dan pengetahuan akan tetapi modal kemauan kemauan masyarakat untuk mengikuti kegiatan pelatihan dan rasa memiliki KUMKM yang cukup besar dengan demikian dapat diindikasikan bahwa tingkat perubahan perilaku masyarakat setelah mengikuti kegiatan pelatihan cukup baik, sedangkan sisanya sebesar 32,85\% perlu dilakukan evaluasi dan tindak lanjut.

Tabel 6

Indikator Tahapan Perubahan Perilaku dan persentase pemahaman materi pengelolaan program dan kelembagaan

\begin{tabular}{|c|c|c|}
\hline Tujuan & Indikator & $\begin{array}{c}\text { Prosentase } \\
\text { Pemahaman }\end{array}$ \\
\hline \multirow{5}{*}{ Pengetahuan } & Masyarakat mengetahui tujuan program KUMKM & 65 \\
\hline & $\begin{array}{l}\text { Masyarakat mengetahui dan memahami penyusunan } \\
\text { program KUMKM. }\end{array}$ & $70 \%$ \\
\hline & $\begin{array}{lrr}\text { Masyarakat mampu } & \text { memahami } & \text { struktur } \\
\text { kelembagaan KUMKM } & & \end{array}$ & $80 \%$ \\
\hline & $\begin{array}{l}\text { Masyarakat mengetahui jenis-jenis buku inventaris, } \\
\text { buku kas KUMKM dan kekayaan KUMKM }\end{array}$ & $70 \%$ \\
\hline & $\begin{array}{l}\text { Masyarakat mampu mengetahui dan memahami } \\
\text { buku laporan pertanggungjawaban keuangan } \\
\text { KUMKM }\end{array}$ & $75 \%$ \\
\hline Sikap & $\begin{array}{l}\text { Masyarakat menerima/ memperhatikan, menilai, } \\
\text { mengorganisir, menanggapi pentingnya administrasi } \\
\text { pengelolaan program dan kelembagaan KUMKM }\end{array}$ & $65 \%$ \\
\hline Keterampilan & $\begin{array}{l}\text { Masyarakat trampil dalam penyusunan buku } \\
\text { administrasi pengelolaan program dan kelembagaan } \\
\text { KUMKM secara sederhana }\end{array}$ & $70 \%$ \\
\hline
\end{tabular}

Sumber: Tim PKM Desa Domas Pontang, 2020

Pada tabel 6 digambarkan bahwa ratarata perubahan perilaku aparatur dan masyarakat desa sebesar $67,14 \%$ atau berdasarkan skala interval evaluasi pengukuran kapasitas masyarakat berada pada kategori
Kemudian untuk mengetahui bagaimana tingkat keberhasilan pencapaian kegiatan pendampingan pelatihan komunikasi pemasaran dilakukan evaluasi melalui indikator tahapan perubahan perilaku pengetahuan, sikap 
dan keterampilan yang dapat dilihat pada tabel

7 sebagai berikut : sebesar 37,50\% perlu dilakukan evaluasi lebih lanjut. Selain itu, pada tahap ini masyarakat

Tabel 7

Indikator Tahapan Perubahan Perilaku dan persentase pemahaman materi Bimbingan Komunikasi Pemasaran

\begin{tabular}{llc}
\hline \multicolumn{1}{c}{ Tujuan } & \multicolumn{1}{c}{ Indikator } & $\begin{array}{c}\text { Persentase } \\
\text { Pemahaman }\end{array}$ \\
\hline \multirow{2}{*}{ Pengetahuan } & $\begin{array}{l}\text { Masyarakat mengetahui dan memahami definisi } \\
\text { pemasaran dan jenis-jenisnya }\end{array}$ & $60 \%$ \\
\cline { 2 - 3 } & $\begin{array}{l}\text { Masyarakat mengetahui konten pemasaran di media } \\
\text { sosial }\end{array}$ & $60 \%$ \\
\hline \multirow{2}{*}{ Sikap } & $\begin{array}{l}\text { Masyarakat mampu membangun sikap positif } \\
\text { terhadap aspek komunikasi pemasaran KUKM }\end{array}$ & \\
\hline Keterampilan & $\begin{array}{l}\text { Masyarakat mengetahui dan memahami pembuatan } \\
\text { kontent pemasaran berbasis media sosial }\end{array}$ \\
\hline & \multicolumn{2}{c}{ Rata-rata } \\
\hline
\end{tabular}

Sumber: Tim PKM Desa Domas Pontang, 2020

Pada tabel 7 digambarkan bahwa ratarata perubahan perilaku aparatur dan masyarakat desa sebesar 62,50\% atau berada pada kategori cukup, hal ini disebabkan masyarakat menilai bahwa komunikasi pemasaran produk KUMKM sangat penting untuk dipahami dan diketahui seluruh masyarakat. Dengan demikian dapat diindikasikan bahwa tingkat perubahan perilaku masyarakat setelah mengikuti kegiatan pelatihan cukup baik, sedangkan sisanya yang tergabung dalam KUMKM diberikan bimbingan pelatihan untuk melakukan penyusunan rencana kerja KUMKM berdasarkan prioritas kebutuhan dan jangka waktu tertentu.

Kegiatan yang dilaksanakan pada tanggal 11 Januari 2020 ini dilakukan bersamasama dengan aparatur desa sebagai pihak penanggung jawab utama kegiatan dan berikut adalah deskripsi hasil perumusan rencana kerja KUMKM Desa Domas Kecamatan Pontang yang dapat dilihat pada tabel.

\section{Tabel 8}

Rencana Kerja KUMKM Desa Domas

\begin{tabular}{|c|c|c|c|}
\hline No & Rencana Kerja & Prioritas & $\begin{array}{l}\text { Waktu Pelaksanaan } \\
\text { sampai dengan selesai }\end{array}$ \\
\hline 1 & $\begin{array}{l}\text { Pendataan anggota KUKM secara up to } \\
\text { date }\end{array}$ & Sangat tinggi & Satu minggu \\
\hline 2 & $\begin{array}{l}\text { Penyediaan buku administrasi KUKM, } \\
\text { alat tulis pendukung (whiteboard, spidol) } \\
\text { lainnya }\end{array}$ & Sangat tinggi & Satu minggu \\
\hline 3 & $\begin{array}{l}\text { Penyediaan inventaris laptop, printer, } \\
\text { kertas }\end{array}$ & Sangat tinggi & Satu minggu \\
\hline 4 & $\begin{array}{l}\text { Penyusunan proposal kerjasama } \\
\text { pembuatan sentra industri ke Dinas } \\
\text { Koperasi Perindustrian dan Perdagangan }\end{array}$ & Sangat tinggi & Dua minggu \\
\hline 5 & Kerjasama dengan BUMDes & Sangat tinggi & Dua minggu \\
\hline 6 & Pembuatan website profil KUKM & Sangat tinggi & Dua minggu \\
\hline 7 & $\begin{array}{l}\text { Pembuatan konten promosi di media } \\
\text { sosial dan konvensional }\end{array}$ & & Dua minggu \\
\hline 8 & $\begin{array}{l}\text { Kerjasama dengan KUKM bidang sejenis } \\
\text { dan tidak sejenis }\end{array}$ & Sangat tinggi & Satu bulan \\
\hline 9 & Studi Banding ke KUKM daerah lain & Sedang & 3 bulan \\
\hline 10 & Rapat anggota KUKM & Sedang & 4 bulan \\
\hline
\end{tabular}

Sumber: Tim PKM Desa Domas Pontang, 2020 


\section{Kesimpulan}

Dari kegiatan yang telah dilaksanakan, dapat disimpulkan beberapa hal sebagai berikut:

a) Tingkat keberhasilan pencapaian dengan menggunakan indikator perubahan perilaku untuk kegiatan pelatihan administrasi pengelolaan program dan kelembagaan KUMKM sertta bimbingan komunikasi pemasaran adalah sebesar $67.14 \%$ dan $62.750 \%$ atau berdasarkan skala interval evaluasi pengukuran kapasitas masyarakat berada pada kategori cukup baik.

b) Masyarakat Kawasan Pantai Utara Desa Domas Kecamatan Pontang Kabupaten Serang sebagai mitra pengabdian masyarakat memiliki tingkat respon dan antusias yang cukup baik meskipun dengan segala keterbatasan yang dimiliki.

c) Kegiatan pengabdian masyarakat masyarakat antara tim pengabdian bersamasama masyarakat di Desa Domas dan tim PKM melalui kegiatan peningkatan kapasitas ekonomi masyarakat melalui pemberdayaan KUMKM berjalan sesuai dengan rencana dan target yang telah ditetapkan.

\section{REFERENSI}

Abdoellah, O. S., Sunardi, S., Widianingsih, I., \& Cahyandito, M. F. (2019). Pemetaan Sosial Dalam Perencanaan Program Pengembangan Ekowisata Berkelanjutan Citarum Hulu. Kumawula: Jurnal Pengabdian Kepada Masyarakat, 2(1), 59. kumawula.v2i1.24461 https://doi.org/10.24198/

Chambers, R. (1994). The origins and practice of participatory rural appraisal. World Development, 22(7), 953-969. https://doi.org/10.1016/0305750X(94)90141-4

Ekosafitri, K. H., Rustiadi, E., \& Yulianda, F. (2017). Pengembangan Wilayah Pesisir Pantai Utara Jawa Tengah Berdasarkan Infrastruktur Daerah: Studi Kasus Kabupaten Jepara. Journal of Regional and Rural Development Planning, 1(2), 145. https://doi.org/10.29244/ jp2wd.2017.1.2.145-157
Nugroho, I., \& Dahuri, R. (2012).

Pembangunan Wilayah: Perspektif Ekonomi, Sosial dan Lingkungan. Penerbit LP3ES.

Sumodiningrat, G. (1999). Jaring Pengaman Sosial dan Pemberdayaan Masyarakat. Ekonomi Dan Bisnis Indonesia, 14(3).

Sururi, A., \& Mulyasih, R. (2017)

Pemberdayaan Masyarakat melalui Inovasi Perencanaan Pembangunan berbasis 4R ( Rembug , Rencana , Realisasi dan Rawat ) di Desa Cilangkap Kecamatan Wanasalam sebagai Pilar Utama Kebijakan Partisipatif dan Gotong Royong. Engagament Jurnal Pengabdian Masyarakat, 1(2).

Widodo, Y. (2007). Modernisasi Perdesaan di Era Globalisasi. Media Indonesia. http://lipi.go.id/berita/modernisasipedesaan-di-era-globalisasi/1536 